Note

\title{
COLD STORAGE OF 'TAHITI' LIME TREATED WITH 1-METHYLCYCLOPROPENE
}

\author{
Maria Luiza Lye Jomori ${ }^{1}$; Ricardo Alfredo Kluge ${ }^{1 *}$; Angelo Pedro Jacomino ${ }^{2}$ \\ ${ }^{1}$ USP/ESALQ, Depto. de Ciências Biológicas, C.P. 9 - 13418-900 - Piracicaba, SP - Brasil. \\ ${ }^{2}$ USP/ESALQ - Depto. de Produção Vegetal. \\ *Corresponding author < rakluge@esalq.usp.br>
}

\begin{abstract}
The storage of 'Tahiti' limes under low temperatures enables the extension of the commercialization period. However the loss of the skin green color and the occurrence of chilling injuries prevent such advantage. The purpose of this work was to verify the efficiency of 1-methylcyclopropene (1MCP), an inhibition of ethylene action, during the cold storage of 'Tahiti' lime. Fruits were treated for 12 hours with 1-methylcyclopropene at concentrations of 0 or $1.0 \mu \mathrm{L} \mathrm{L}^{-1}$ and then were stored at 5 or $10^{\circ} \mathrm{C}$ for 30,60 and 90 days of storage ( +3 days of simulated marketing at $20^{\circ} \mathrm{C}$ ). Application of 1-MCP conserved the color of stored fruits at $10^{\circ} \mathrm{C}$ during 30 days. Fruits treated with 1-MCP and stored at $5^{\circ} \mathrm{C}$ presented less respiration than non-treated fruits. High levels of ethanol and acetaldehyde were observed after 60 days in non-treated fruits. The occurrence of chilling injuries on fruits was not verified after a 30-day storage period, however after 60 days of storage, 40 to $58 \%$ of fruits kept at $5^{\circ} \mathrm{C}$ presented chilling injuries. All fruits stored at $5^{\circ} \mathrm{C}$ presented chilling injuries after 90 days.

Key words: Citrus latifolia, chilling injury, ethanol, acetaldehyde
\end{abstract}

\section{ARMAZENAMENTO REFRIGERADO DE LIMAS 'TAHITI' TRATADAS COM 1-METILCICLOPROPENO}

\begin{abstract}
RESUMO: A conservação refrigerada da lima ácida 'Tahiti' sob baixa temperatura permite o aumento no período de comercialização dos frutos. Entretanto a perda da coloração verde da casca e a incidência de injúrias pelo frio impedem este prolongamento. O objetivo do presente projeto foi verificar a eficiência do 1metilciclopropeno (1-MCP), um inibidor da ação do etileno durante a conservação refrigerada de lima ácida 'Tahiti'. Os frutos foram submetidos aos tratamentos com 1-metilciclopropeno, durante 12 horas, nas concentrações de 0 e $1,0 \mu \mathrm{L} \mathrm{L}^{-1}$ e armazenados a 5 e $10^{\circ} \mathrm{C}$. As avaliações foram realizadas após 30,60 e 90 dias de conservação (+ três dias de comercialização simulada a $20^{\circ} \mathrm{C}$ ). Aplicação de 1-MCP manteve a coloração dos frutos armazenados a $10^{\circ} \mathrm{C}$ durante 30 dias. Frutos tratados com 1-MCP e armazenados a $5^{\circ} \mathrm{C}$ apresentaram menor taxa respiratória que frutos não tratados. Altos níveis de etanol e acetaldeído foram observados após 60 dias em frutos não tratados com 1-MCP. Não foram verificadas injúrias pelo frio nos frutos após 30 dias de armazenamento. Após 60 dias, 48 a 58\% dos frutos armazenados a $5^{\circ} \mathrm{C}$ apresentaram injúrias pelo frio. Após 90 dias, todos os frutos armazenados a $5^{\circ} \mathrm{C}$ apresentaram injúrias pelo frio.

Palavras-chave: Citrus latifolia, injúrias pelo frio, etanol, acetaldeído
\end{abstract}

\section{INTRODUCTION}

The 1-methylcyclopropene (1-MCP) is a gaseous compound recently discovered as an efficient inhibitor of the ethylene action (Serek et al., 1995). 1-MCP binds to ethylene and acts as an antagonist. It has great potential for commercial use to control ripening process in fruits and vegetables, as well as senescence in flowers (Sisler \& Serek, 1997).

Although non-climacteric fruits, such as citrus, present only the system 1 for ethylene production, with low ethylene production (Vendrell \& Palomer, 1997), this does not mean that there is no ethylene interference on fruit maturation. Ethylene, even at low concentrations, affects non-climacteric fruits, mainly for those of ethylene threshold level above $0.005 \mu \mathrm{L} \mathrm{L}^{-1}$, and when the level of ethylene that accumulates around fruits in commercial situations is much greater than $0.005 \mu \mathrm{L} \mathrm{L}^{-1}$ (Wills et al., 1999). Therefore, ethylene is involved in maturation-related events, such as chlorophyll degradation of the skin (Goldschmidt, 1997), and it is possible that the skin green coloration loss in some citrus cultivars can be delayed by the application of 1-MCP, because of its influence on the ethylene action. This product not only increases the storage of non-climacteric products, such as 'Shamouti' oranges (Porat et al., 1999), straw- 
berries (Ku et al., 1999) and broccolis (Ku \& Wills, 1999), but also delays ripening of several climacteric fruits, such as plums (Abdi et al., 1998), bananas (Jiang et al., 1999), apples (Fan et al., 1999), avocados (Feng et al., 2000), peaches (Kluge \& Jacomino, 2002), and papaya (Jacomino et al., 2002).

The maintenance of the skin green coloration of 'Tahiti' lime fruits (Citrus latifolia, Tanaka) is desirable during storage for better commercialization. As the green color fades, fruit acceptance gradually decreases (Manfroi et al., 1996). The 'Tahiti' lime is harvested when presenting green color, after reaching full development, and commercialized while the skin is still green. The chlorophyll degradation processes and the carotenoid synthesis are, however, still in progress under room temperature conditions during marketing, and end up causing green color loss (Sinclair, 1984; Baldwin, 1994). This also happens with fruits kept under refrigeration, although in this case the degreening speed is slower.

The best storage conditions for 'Tahiti' lime storage are: temperature ranging from 10 to $12^{\circ} \mathrm{C}$ and relative humidity from 85 to $95 \%$. Under such conditions, fruits can be stored for 4 to 8 weeks. Long periods of temperatures below $8^{\circ} \mathrm{C}$ induce chilling injuries to fruits, characterized by superficial pitting and increase of rot incidence (Kader \& Arpaia, 1992; Kluge et al., 2001).

The purpose of the present study was to investigate the role of an inhibitor of the ethylene action during the cold storage of 'Tahiti' lime at chilling inductive and non-chilling inductive temperatures.

\section{MATERIAL AND METHODS}

The experiment was carried out using 'Tahiti' acid lime fruits harvested at commercial orchard located in Mogi-Guaçu, SP $\left(16^{\circ} 05^{\prime} 13^{\prime \prime} \mathrm{S}, 38^{\circ} 57^{\prime} 10^{\prime \prime} \mathrm{W}\right)$. Orchard trees were eight years old and were submitted to ordinary soil management practices, irrigation, application of nutrients and disease control. Fruits were selected according to size (50 mm diameter, $\pm 3 \mathrm{~mm}$ ) and color (intense green), and submitted to 1-methylclopropopene (1-MCP, Smartfresh $^{\circledR}$, AgroFresh Inc., USA) treatments at the recommended concentration of $1.0 \mu \mathrm{L} \mathrm{L}^{-1}$ inside $186-\mathrm{L}$, hermetic boxes. The commercial product was introduced into lidded flasks with $30 \mathrm{~mL}$ of distilled water at $50^{\circ} \mathrm{C}$, and stirred until complete dissolution. Flasks were then opened in the chambers, which were immediately sealed. Fruits were submitted to treatment for 12 -hour at $20^{\circ} \mathrm{C}$. Chambers were then opened and half of the fruits were transferred to a refrigerated chamber at $10^{\circ} \mathrm{C}$, while the remaining fruits were kept at $5^{\circ} \mathrm{C}$. The relative humidity varied from 85 to $90 \%$. Fruits were stored for 90 days and samples were taken for analysis at the $30^{\text {th }}, 60^{\text {th }}$ and $90^{\text {th }}$ days of treatment, and were kept in a simulated marketing period of 3 days at $20^{\circ} \mathrm{C}$. A completely ran- domized experimental design with four treatments and five replications of ten fruits was used for each storage period.

The analyzed characteristics were:

a) chilling injuries: the percentage of affected fruits and chilling injury severities; fruits were classified in five categories, according to the affected surface area: $0=0 \%$, $1<5 \%, 2=5-25 \%, 3=25-50 \%$, and $4>50 \%$;

b) skin color: evaluated using a Minolta Chroma Meter CR-300, which provided measurements of the hue angle $\left(\mathrm{h}^{\circ}\right)$ and chroma $\left(\mathrm{C}^{*}\right)$; hue angle values greater than $90^{\circ}$ represent greener fruits and values closer to $90^{\circ}$ represent yellowish fruits; chroma defines the color intensity, and values around zero represent neutral colors (gray) and values around 60, bright colors (McGuire, 1992); higher $\mathrm{C}^{*}$ values represent more intense yellow color;

c) juice percentage: after weighing (FM), juice was extracted (JM) from fruits of each replicate, and juice percentage was determined as follows: $\%$ juice $=(\mathrm{JM} / \mathrm{FM}) \times 100$;

d) total soluble solids (TSS): measured through a digital refractometer ATAGO, model Palette with automatic temperature correction to $20^{\circ} \mathrm{C}$;

e) total titratable acidity (TTA): $10 \mathrm{~mL}$ of juice were mixed into $90 \mathrm{~mL}$ of distilled water and potentiometric titration of solution with $1 \mathrm{~N} \mathrm{NaOH}$ was carried out until the $\mathrm{pH}$ reached 8.10 ;

f) TSS/TTA ratio;

g) technological index (TI): $\mathrm{TI}=(\mathrm{TSS} \times \%$ juice $) / 100$;

h) vitamin C level: 10-mL aliquots of juice were poured into Erlenmeyer flasks containing $50 \mathrm{~mL}$ of oxalic acid solution; followed titration with DCIP (2,6 dichlorophenolindophenol) until a pinkish color persisted for 15 seconds, expressing results in $\mathrm{mg}$ of ascorbic acid per $100 \mathrm{~mL}$ of juice;

i) respiratory rate: 10 -fruit samples from each treatment were kept for three hours into 5-L, hermetic glass pots with rubber septum on lids, through which gas samples were taken with $1-\mathrm{mL}$ syringes and analyzed through a $\mathrm{CO}_{2}$ and $\mathrm{O}_{2}$ analyzer (Dansensor);

j) ethanol and acetaldehyde contents: ethanol and acetaldehyde contents were determined according to methodology suggested by Cohen et al. (1990); 10-mL aliquots of juice were placed into a 50-mL Erlenmeyer flask and incubated in a stirrer for 7 minutes; a 1-mL air sample was taken from the empty space of the flasks and injected into a gas chromatographer (GC 37370); results were expressed in $\mu \mathrm{L} \mathrm{L}^{-1}$.

Data were submitted to ANOVA ( $\mathrm{F}$ test) and means compared by Tukey test $(P=0.05)$ 


\section{RESULTS AND DISCUSSION}

Fruits kept at $10^{\circ} \mathrm{C}$ presented greater losses of green skin coloration as compared to those stored at $5^{\circ} \mathrm{C}$ (Tables 1 and 2). Such results were expected, considering that the speed of metabolic reactions is directly related to temperature. After 30 days of storage, fruits stored at $10^{\circ} \mathrm{C}$ had the lowest hue angle $\left(\mathrm{h}^{\circ}\right)$ values, that is, they were less green, especially the non 1-MCP treated fruits, with $\mathrm{h}^{\circ}$ values of 110 (Table 1). After 60 days, fruits stored at $10^{\circ} \mathrm{C}$ presented completely yellow skin coloration, with the lowest $\mathrm{h}^{\circ}$ values between 94 and 99, and the greatest $C^{*}$ values between 48 and 54 . Within this period and temperature, no effect related to $1-\mathrm{MCP}$ was verified (Table 2). The treatment that best preserved skin green coloration was fruits treated with 1-MCP and stored at $5^{\circ} \mathrm{C}-\mathrm{h}^{\circ}$ values $=118$ and $\mathrm{C}^{*}=32$. These fruits were still suitable for commercialization, despite presenting initial chilling symptoms.

Fruits treated with 1-MCP maintained their green coloration as compared to the non-treated, at both temperatures, resulting from a delay of the ethylene action, probably associated to a lower activity of the chlorophyllase enzyme, that degrades the chlorophyll molecule which makes skin yellow. Chlorophyll degradation is an event that can be regulated by ethylene (Goldschmidt, 1997). Consequently, inhibitors of this hormone action, such as 1-MCP, can delay green color fad-

Table 1 - Treatments effect on hue angle $\left(\mathrm{h}^{\circ}\right)$, chroma $\left(\mathrm{C}^{*}\right)$, respiratory rate, ethanol and acetaldehyde amounts of 'Tahiti' lime after 30 days of storage at 5 or $10^{\circ} \mathrm{C}$ (+ 3 days at $20^{\circ} \mathrm{C}$ ).

\begin{tabular}{|c|c|c|}
\hline \multirow{2}{*}{$1-\mathrm{MCP}$} & \multicolumn{2}{|c|}{ Temperature } \\
\hline & $10^{\circ} \mathrm{C}$ & $5^{\circ} \mathrm{C}$ \\
\hline$\mu \mathrm{L} \mathrm{L}^{-1}$ & \multicolumn{2}{|c|}{ - } \\
\hline 0 & $110 \mathrm{bB}$ & $120 \mathrm{aA}$ \\
\hline \multirow[t]{2}{*}{1} & $118 \mathrm{aA}$ & $121 \mathrm{aA}$ \\
\hline & \multicolumn{2}{|c|}{ - Chroma (C*) - } \\
\hline 0 & $39.09 \mathrm{aA}$ & $31.55 \mathrm{aB}$ \\
\hline \multirow[t]{2}{*}{1} & $37.66 \mathrm{aA}$ & $29.28 \mathrm{aB}$ \\
\hline & \multicolumn{2}{|c|}{----- Respiratory rate $\left(\mathrm{mL} \mathrm{CO}_{2} \mathrm{~kg}^{-1} \mathrm{~h}^{-1}\right)$----- } \\
\hline 0 & $15.43 \mathrm{aA}$ & $13.05 \mathrm{aA}$ \\
\hline \multirow[t]{2}{*}{1} & $14.64 \mathrm{aA}$ & $10.45 \mathrm{bB}$ \\
\hline & \multicolumn{2}{|c|}{ - } \\
\hline 0 & $90.33 \mathrm{aA}$ & $95.66 \mathrm{aA}$ \\
\hline \multirow[t]{2}{*}{1} & $98.33 \mathrm{aA}$ & $98.34 \mathrm{aA}$ \\
\hline & \multicolumn{2}{|c|}{ Acetaldehyde $\left(\mu \mathrm{L} \mathrm{L}^{-1}\right)$} \\
\hline 0 & $9.34 \mathrm{aA}$ & $8.67 \mathrm{aA}$ \\
\hline 1 & $9.66 \mathrm{aA}$ & $9.67 \mathrm{aA}$ \\
\hline
\end{tabular}

Mean separation by capital letter in column and small letter in lines by Tukey test at $P \leq 0.05$. ing. In addition, fruits treated with 1-MCP and stored at $10^{\circ} \mathrm{C}$ maintained the green coloration similarly to control fruits kept at $5^{\circ} \mathrm{C}$, which demonstrates a beneficial effect of the 1-MCP treatment on color maintenance.

After 30 days, fruits stored at $5^{\circ} \mathrm{C}$ presented lower respiratory rate in comparison to fruits kept at $10^{\circ} \mathrm{C}$, while fruits treated with $1-\mathrm{MCP}$ and stored at $5^{\circ} \mathrm{C}$ presented over respiration than non-treated fruits (Table 1). The 1MCP, besides blocking the action of ethylene, decreases the respiratory rate, taking into consideration that the action of this hormone includes enhancement of the respiratory metabolism. This reduction on respiration was also observed for papaya treated with 1-MCP (Jacomino et al., 2002). There was no difference for respiratory rate among treatments after 60 days of storage (Table 2). There was a decline on respiration from 30 to 60 days, since the lime is a non-climacteric fruit which frequently presents a constant reduction on the respiratory rate after harvest.

Regarding the analyses of ethanol and acetaldehyde, fruits did not presented alterations of the respiratory metabolism after 30 days, while higher levels of fermentation products were observed after 60 days in nontreated fruits (Tables 1 and 2). Yet, informal sensorial analysis evidenced the presence of odd smells, produced by the fermentative processes. The 1-MCP, besides retarding respiration, apparently avoids fermentative processes. No differences were observed in the physicochemical characteristics of fruits among treatments. TSS

Table 2 - Treatments effect on hue angle $\left(\mathrm{h}^{\circ}\right)$, chroma $\left(\mathrm{C}^{*}\right)$, respiratory rate, ethanol and acetaldehyde amounts of 'Tahiti' lime after 60 days of storage at 5 or $10^{\circ} \mathrm{C}$ (+ 3 days at $20^{\circ} \mathrm{C}$ ).

\begin{tabular}{|c|c|c|}
\hline $1-\mathrm{MCP}$ & \multicolumn{2}{|c|}{ Temperature } \\
\hline & $10^{\circ} \mathrm{C}$ & $5^{\circ} \mathrm{C}$ \\
\hline$\mu \mathrm{L} \mathrm{L}^{-1}$ & \multicolumn{2}{|c|}{ 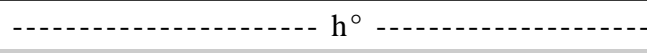 } \\
\hline 0 & $94.87 \mathrm{aB}$ & $112.72 \mathrm{bA}$ \\
\hline \multirow[t]{2}{*}{1} & $99.82 \mathrm{aB}$ & $118.27 \mathrm{aA}$ \\
\hline & \multicolumn{2}{|c|}{ - } \\
\hline 0 & $54.55 \mathrm{aA}$ & $41.81 \mathrm{aB}$ \\
\hline \multirow[t]{2}{*}{1} & $48.23 \mathrm{aA}$ & $32.89 \mathrm{bB}$ \\
\hline & \multicolumn{2}{|c|}{----- Respiratory rate $\left(\mathrm{mL} \mathrm{CO}_{2} \mathrm{~kg}^{-1} \mathrm{~h}^{-1}\right)$} \\
\hline 0 & $7.76 \mathrm{aA}$ & $6.33 \mathrm{aA}$ \\
\hline \multirow[t]{2}{*}{1} & $6.98 \mathrm{aA}$ & $6.97 \mathrm{aA}$ \\
\hline & \multicolumn{2}{|c|}{ - Ethanol $\left(\mu \mathrm{L} \mathrm{L}^{-1}\right)-\ldots$} \\
\hline 0 & $90.33 \mathrm{aA}$ & $95.66 \mathrm{aA}$ \\
\hline \multirow[t]{2}{*}{1} & $98.33 \mathrm{aA}$ & $98.34 \mathrm{aA}$ \\
\hline & \multicolumn{2}{|c|}{ - Acetaldehyde $\left(\mu \mathrm{L} \mathrm{L}^{-1}\right)$} \\
\hline 0 & $19.06 \mathrm{Aa}$ & $19.00 \mathrm{aA}$ \\
\hline 1 & $13.01 \mathrm{bA}$ & $8.67 \mathrm{bA}$ \\
\hline
\end{tabular}

Mean separation by capital letter in column and small letter in lines by Tukey test at $P \leq 0.05$. 
varied from 7.35 to $8.32{ }^{\circ}$ Brix; TA from 5.25 to $6.98 \%$ citric acid, and C vitamin from 21.66 to $28.79 \mathrm{mg} 100$ $\mathrm{mL}^{-1}$. The juice percentage and TI varied from 42.20 to $46.41 \%$ and from 3.21 to 3.76 , respectively (data not shown).

No injuries resulting from chilling or rots were observed in fruits stored at $5^{\circ} \mathrm{C}$ after 30 days in any treatment. The occurrence of chilling symptoms depends on both, temperature and time of exposure to this temperature (Chitarra \& Chitarra, 1990). In the present work, the 30-day exposure period at $5^{\circ} \mathrm{C}$ was not enough to induce chilling injuries. On the $60^{\text {th }}$ day of storage, the incidence of chilling injuries varied from 40 to $58 \%$, being characterized by small black superficial pits on fruit skin, which were verified only in fruits kept at $5^{\circ} \mathrm{C}$. There was no interference of 1-MCP on chilling injury incidence. After 90 days of refrigerated storage, fruits from all treatments were affected by chilling injuries, becoming yellowish and presenting high weight loss, becoming unsuitable for commercialization (data not shown).

\section{ACKNOWLEDGEMENTS}

To Dr. Walter Pereira, Rohm and Haas, for providing the $1-\mathrm{MCP}$, and to FAPESP for providing a fellowship to the main author and $\mathrm{CNPq}$ for fellowships to the last two authors.

\section{REFERENCES}

ABDI, N.; McGLASSON, W.B.; HOLFORD, P.; WILLIAMS, M.; MIZRAHI, Y. Responses of climacteric and suppressed-climacteric plums to treatment with propylene and 1-methylcyclopropene. Postharvest Biology and Technology, v.14, p.29-39, 1998.

BALDWIN, E.A. Citrus fruit. In: SEYMOUR, G.B.; TAYLOR, J.E.; TUCKER, G.A. (Ed.) Biochemistry of fruit ripening. London: Chapman \& Hall, 1994. chap.8, p.255-271.

CHITARRA, M.I.; CHITARRA, A.B. Pós-colheita de frutos e hortaliças: fisiologia e manuseio. Lavras: ESAL, FAEPE, 1990. 320p.

COHEN, E.; BEN-YEHOSHUA, S.; ROSENBERGER, I.; SHALON, Y.; SHAPIRO ARO, B. Quality of lemons sealed in high-density polyethylene film during long-term storage at different temperatures whith intermittent warming. Journal of Horticultural Science, v.65, p.603-610, 1990.

FAN, X.; BLANKENSHIP, S.M.; MATTHEIS, J.P. 1-methylcyclopropene inhibits apple ripening. Journal of the American Society for Horticultural Science, v.124, p.690-695, 1999.
FENG, X.; APELBAUM, A.; SISLER, E.C.; GOREN, R. Control of ethylene responses in avocado fruit with 1-methylcyclopropene. Portharvest Biology and Technology, v.20, p.143-150, 2000.

GOLDSCHMIDT, E.E. Ripening of citrus and other non-climateric fruits: a role for ethylene. Acta Horticulturae, n.463, p.325-334, 1997.

JACOMINO, A.P.; KLUGE, R.A.; BRACKMANN, A.; CASTRO, P.R.C Amadurecimento e senescência de mamão com 1-metilciclopropeno. Scientia Agricola, v.59, p.303-308, 2002.

JIANG, Y.; JOYCE, D.C.; MACNISH, A.J. Extension of the shelf life of banana fruit by 1-methylcyclopropene in combination with polyethylene bags. Postharvest Biology and Technology, v.16, p.187-193, 1999.

KADER; A.A.; ARPAIA, M.L. Postharvest handling system: subtropical fruits. In: KADER, A.A. (Ed.) Postharvest technology of horticultural crops. 2.ed. Oakland: University of California, 1992. p.233-240.

KLUGE, R.A.; JACOMINO, A.P. Shelf life of peaches treated with 1methylcyclopropene. Scientia Agricola, v.59, p.69-72, 2002.

KLUGE, R.A.; SCARPARE FILHO, J.A.; JACOMINO, A.P.; PEIXOTO, C.P. Distúrbios fisiológicos em frutos. Piracicaba: FEALQ, 2001 $58 \mathrm{p}$.

KU, V.V.V.; WILLS, R.B.H. Effect of 1-methylcyclopropene on the storage life of broccoli. Postharvest Biology and Technology, v.17, p.127-132, 1999.

KU, V.V.V.; WILLS, R.B.H.; BEN-YEHOSHUA, S. 1-Methylcyclopropene can differentially affect the postharvest life of strawberries exposed to ethylene. HortScience, v.34, p.119-120, 1999

MANFROI, V.; LUCCHESE, O.A.; CARVALHO, R.I.N.; FIORAVANÇO, J.C.; BENDER, R.J. Efeito do 2,4-D na frigoconservação de limão Tahiti (Citrus latifolia Tanaka). Boletin Ceppa, v.14, p.77-88, 1996.

McGUIRE, R.G. Reporting of objective color measurements. HortScience, v.27, p.1254-1255, 1992

PORAT, R.; WEISS, B.; COHEN, L.; DAUS, A.; GOREN, R.; DROBY, S. Effects of ethylene and 1-methylcyclopropene on the postharvest qualities of 'Shamouti' oranges. Postharvest Biology and Technology, v.15, p.155-163, 1999.

SEREK, M.; SISLER, E.C.; REID, M.S. 1-Methylcyclopropene, a novel gaseous inhibitor of ethylene action, improves the life of fruit, cut flowers and potted plants. Acta Horticulturae, n.394, p.337-345, 1995

SINCLAIR, W.B. The biochemistry and physiology of the lemon and other citrus fruits. Oakland: University of California, 1984. 946p.

SISLER, E.C.; SEREK, M. Inhibitors of ethylene responses in plants at the receptors level: recent developments. Physiologia Plantarum, v.100, p.577-582, 1997.

VENDRELL, M.; PALOMER, X. Hormonal control of fruit ripening in climacteric fruits. Acta Horticulturae, n.463, p.325-334, 1997.

WILLS, R.B.H.; KU, V.V.V.; SHOHET, D.; KIM, G.H. Importance of low ethylene levels to delay senescence of non-climacteric fruit and vegetables. Australian Journal of Experimental Agriculture, v.39, p.221-224, 1999

Received August 22, 2002

Accepted July 31, 2003 